\title{
DAMPAK SOSIAL TERHADAP RENCANA PEMBANGUNAN PERUMAHAN REGIONAL DI KAWASAN PANGI DESA LATALI KECAMATAN PAKUE TENGAH KABUPATEN KOLAKA UTARA
}

\author{
Eri Pranata ${ }^{1}$, Muhlis Madani ${ }^{2}$, Jamaluddin Arifin ${ }^{3}$ \\ ${ }^{1}$ Pendidikan Sosiologi, Universitas Muhammadiyah Makassar \\ Email: eripranata@gmail.ac.id \\ ${ }^{2}$ Pendidikan Sosiologi, Universitas Muhammadiyah Makassar \\ Email: muhlismadani@unismuh.ac.id \\ ${ }^{3}$ Pendidikan Sosiologi, Universitas Muhammadiyah Makassar \\ Email: jamaluddinarifin@unismuh.ac.id
}

\begin{abstract}
The lives of people who continue to experience changes, where their livelihoods also change. This situation is inseparable from the construction of housing which results in the use of agricultural land which is a source of livelihood for the surrounding community. The location of housing development close to settlement settlements will have various positive and negative social impacts. The purpose of this study is to find out how the social impact of regional housing development in the Pangi area on the surrounding community, knowing how the social impact of housing development with communities around housing. The number of research informants as many as 7 people was determined by purposive sampling. Criteria for informants are key and ordinary informants with people who have sold their land, residential residents who have lived for at least 5 years, government officials, religious leaders, community leaders and youth leaders. Data collection techniques through observation, interviews, and documentation and analyzed qualitatively. The results of this study indicate that the use of agricultural land that occurs due to housing development causes changes in community life patterns resulting in various social impacts among the community, where people with inadequate skills and education require them to only work as construction workers, vegetable sellers, fish sellers and working as a watering garden in housing with uncertain income makes it even more difficult to manage the needs of his family and the people who sell their land return to buy land elsewhere. Social relations arising from the presence of housing complexes that have good employment and educational background in the neighborhoods of settlements have a positive impact, the wider breadth of association, insight, cleaner lifestyle and the desire to continue higher education to get formal sector employment. As for the negative impact of disagreement or friction because of misunderstanding, it always causes symptoms of cultural boundaries so that the potential for jealousy and social conflict arises.
\end{abstract}

Keywords: Development, Social Impacts of Community Life.

Abstrak. Kehidupan masyarakat yang terus mengalami perubahan, dimana mata pencahariannyapun mengalami perubahan. Setuasi ini tidak terlepas dari pembangunan perumahan yang mengakibatkan terjadi penggunaan lahan pertanian yang merupakan sumber penghidupan masyarakat sekitar. Lokasi pembangunan perumahan berdekatan dengan pemukiman perkampungan akan menimbulkan berbagai dampak sosial baik positif maupun negatif.

Tujuan penelitian ini adalah mengetahui bagaimana dampak sosial pembangunan perumahan regional di kawasan pangi terhadap masyarakat sekitar, mengetahui bagaimana dampak sosial pembangunan perumahan dengan masyarakat sekitar perumahan. Jumlah informan penelitian sebanyak 7 orang ditentukan secara purposive sampling. Kriteria informan yaitu informan kunci dan biasa dengan masyarakat yang telah menjual lahannya, warga masyarakat perumahan yang telah tinggal minimal 5 tahun, aparat pemerintah, tokoh agama, 
tokoh masyarakat dan tokoh pemuda. Tehnik pengumpulan data melalui observasi, wawancara, dan dokumentasi dan dianalisis secara kualitatif.

Hasil penelitian ini menunjukkan penggunaan lahan pertanian yang terjadi karena adanya pembangunan perumahan menyebabkan terjadinya perubahan pola kehidupan masyarakat mengakibatkan berbagai dampak sosial di kalangan masyarakat, dimana masyarakat dengan skill dan pendidikan yang tidak memadai mengharuskan mereka hanya bekerja sebagai buruh bangunan, penjual sayur, penjual ikan dan bekerja sebagai penyiram taman di perumahan dengan pendapatan yang tidak menentu membuatnya semakin kesulitan dalam mengatur kebutuhan keluarganya dan adapun masyarakat yang menjual lahannya kembali membeli lahan ditempat lain. Hubungan sosial yang ditimbulkan dengan keberadaan kompleks perumahan yang mempunyai latar belakang pekerjaan dan pendidikan yang baik di lingkungan pemukiman perkampungan menimbulkan dampak positif, semakin luasnya pergaulan, wawasan, gaya hidup lebih bersih dan adanya keinginan melanjutkan pendidikan lebih tinggi untuk mendapatkan pekerjaan kesektor formal. Adapun dampak negatifnya pertentangan pendapat atau gesekan-gesekan karena kesala pahaman hal itu senantiasa menimbulkan gejala adanya batas budaya sehingga potensi timbulnya kecemburuan dan konflik sosial.

Kata Kunci: Pembangunan, Dampak Sosial Kehidupan Masyarakat.

\section{PENDAHULUAN}

Kota merupakan konsentrasi pemukiman penduduk yang makin lama makin meluas, Umumnya konsentrasi di dalam pemukiman penduduk di daerah perkotaan sangat tinggi kepadatannya di bandingkan daerah pedeesaan, konsentrasi penduduk tersebut menimbulkan kebutuhan kuantitatif, misalnya kebutuhan perumahan, pendidikan, lapangan pekerjaan, kesehatan, rekreasi, fasilitas pelayanan kota seperti air minum, listrik, ankutang umum, komunikasi dan lain sebagainya.

Sejalan dengan pertumbuhan penduduk yang makin meningkat, Indonesia dalam perkembangannya yang dinamis dengan meningkatkan pembangunan di berbagai sektor kehidupan sebagaimana diamanatkan oleh UUD 1945. Salah satu yang menjadi perhatian dan perlu penanganannya adalah dalam sektor perumahan dan pemukiman karena merupakan kebutuhan dasar hidup manusia disamping kebutuhan pokok lainnya seperti sandang, pangan, kesehatan, pendidikan dan kebutuhan lainnya. Pemenuhan kebutuhan akan perumahan merupakan hak individu yang sepenuhnya menjadi tanggung jawab masing-masing individu. Sebagian orang beranggapan belum lengkap kehidupan seseorang apabila belum memiliki rumah sendiri. Namun demikian pemenuhan kebutuhan itu tidak sekedar syarat formal untuk berlindung.Setiap individu selalu berkeinginan agar rumah yang dihuninya memenuhi standar kesehatan, standar konstruksi, tersedianya fasilitas umum, fasilitas sosial dan prasarana lingkungan yang memadai.

Dewasa ini perkembangan daerah pinggiran terbesar dapat dilihat dari adanya alih fungsi (konversi) guna lahan kawasan dari kawasan pertanian ke nonpertanian yang terjadi secara besarbesaran. Hal inilah yang terjadi di kecamatan Latali Kab. Kolaka Utara Di kelurahan Pangi Desa Latali, terjadi ali fungsi lahan perkebunan menjadi area perumahan, hal ini tentu berdampak pada sosial ekonomi masyarakat setempat yang sebelumnya bekerja di sektor pertanian. Masyarakat di sekitar pembagunan perumahan di Keluraan Latali Kecamatan Pakue Tengah Kabupateng kolaka Utara, sebelum adanya pembagunan perumahan mayoritas masyarakat bekerja sebagai petani dan penggarap sawah.

Selain itu, pembagunan perumahan di kawasan pangi Desa Latali merupakan pembagunan perumahan pertama yang di lakukan di kawasan latali kelurahan pangi, yang di manah tempat ini di pilih karna merupakan salah satu tempat yang strategis karna merupakan jalan penhubung utama yang mempunyai batas atministrasi bersebelahan dengan desa kalahunde, yang sebagian besar lokasinya di dominasi oleh lahan perkebunan coklat, kini telah di sentuh oleh pegembangan perumahan yaitu perumahan regional pangi dan memanfaatkan lahan coklat dengan menimbun lahan tersebut untuk penambahan pegembanganya yang akan berpengaruh pada kehidupan sosial maupun ekonomi pada masyarakat yang bermukim di sekitar pembagunan perumahan.

Pembangunan perumahan regional di harapkan mampu menunjan pertumbuhan ekonomi kawasan latali dengan mampu menabah nilai tata ruang kecamatan sebagai salah satu wujud 
pembagunan tata ruang kota lasusua. namun Tanpa adanya pengaturan yang mendasar, alih fungsi ini dengan berbagai dampak negatifnya akan terjadi lebih luas lagi, di orientasikan dalam rangka menjamin kepastian bermukim yang menjamin hak setiap warga negara untuk menempati, menikmati dan atau memiliki rumah yang layak dalam lingkungan yang sehat, aman, serasi dan teratur. Selain itu, hadirnya masyarakat baru yaitu kelas menengah ke atas yang secara geografis tinggal bersama warga setempat, membawa pengaruh tersendiri terhadap perubahan tatanan sosial ekonomi masyarakat setempat. Salah satu contohnya adalah dalam proses gotong royong kebersihan lingkungan, mulanya warga terbiasa gotong royong bersama. Warga kelas menengah di perumahan jarang terlibat di kegiatan gotong royong dan lebih memilih tidak terlibat dengan kegiatan-kegiatan masyarakat setempat, meski mereka tetap memberikan konpensasi berupa uang kepada masyarakat setempat, dengan demikian, masyarakat setempat pun mendapatkan keuntungan.

Dampak sosial muncul ketika terdapat aktivitas-aktivitas pembangunan perumahan yang diterapkan pada suatu masyarakat, ini mempengaruhi pola kehidupan masyarakat dan hubungan sosial. Hubungan sosial masyarakat diperkampungan mereka saling kenal mengenal dengan baik dan hidup bekerja sama melalui tolong menolong, membantu tetangga, kerja bakti, dan sebagainya hal seperti ini menjadi suatu kewajiban saling membalas terutama dalam hal pekerjaan yang berhubungan dengan pertanian atau salah satu warga melakukan perayaan. Hadirnya pembangunan perumahan bentuk interaksi sosial telah mengalami pergeseran.

\section{METODE PENELITIAN}

Jenis penelitian ini adalah kualitatif dengan metode analisis deskriptif yang bertujuan memahami realitas sosioal respon masyarakat mengenai dampak sosial terhadap rencana pembangunan perumahan regional di Kawasan Pangi dan dampak sosial terhadap rencana pembangunan perumahan regional di kawasan Pangi Desa Latali Kecamatan Pakue Tengah Kabupateng Kolaka Utara. Informan ditentukan secara purpose sampling, teknik pengumpulan data yaitu observasi, wawancara, dan dokumentasi, kemudian dianalisis melalui tahapan pengumpulan data (data collection), reduksi data (data reduction), penyajian data (display data), penarikan kesimpulan (conclusion) dan menggunakan teknik keabsahan data triangulasi sumber, teknik, dan waktu.

\section{HASIL DAN PEMBAHASAN}

\section{Respon Masyarakat Mengenai Dampak Sosial Terhadap Rencana Pembangunan Perumahan Regional di Kawasan Pangi}

Respon dalam arti umum mengandung pengertian jawaban atau reaksi terhadap sesuatu. Menurut Kamus Besar Bahasa Indonesia (2002), respon berarti tanggapan; reaksi; jawaban. Respon individu terhadap sesuatu dapat diberikan dalam bentuk ucapan, isyarat, atau tingkah laku yang terobservasi, hal ini tergantung dari kemampuan yang memberikan respon (Rojat, 2001). Respon yang ditunjukkan oleh masyarakat terhadap penerimaan suatu proyek/kegiatan berbeda-beda.

Menurut hasil observasi dan wawancara terdapat bervariasi tanggapan masyarakat setempat yakni ada yang memiliki respon positif, netral dan juga negative. Perbedaan respon terhadap perubahan yang ditunjukkan oleh masyarakat yangterlibat dalam program ada 3 macam yaitu (Sajogyo dan Pudjiwati, 2002):

1. Respon positif: Terjadi jika orang-orang dalam masyarakat setempat, yaknipara penerima suatu unsur baru, terdorong ikut serta mengambil bagian dalamseluruh perencanaan dan pemenuhan proyek tersebut.

2. Respon negatif: Terjadi jika unsur pembaharu tidak berhasil membuat rakyatsetempat ikut serta baik dalam perencanaan maupun dalam pemenuhannya.

3. Respon netral: Terjadi jika pengikutsertaan rakyat setempat tidak relevan dengan hasil rencana tersebut. 
Dari hasil wawancara ada beberapa indicator yang mendukung argument tanggapan dari masing-masing warga setempat. Pertama; respon positif yaitu beberapa informan menyatakan pembangunan tersebut dari pendekatan ekonomi menguntungkan khususnya dalam konteks ini adalah masyarakat yang menjual lahannya. Tolak ukur lainnya adalah dengan pembangunan tersebut menciptakan peluang kerja bagi masyarakat setempat dalam hal pembangunan rumah. sementara yang menanggapi negative adalah memperhatikan dampak lingkungan dari pembangunan tersebut seperti kondisi lingkungan gersang dan limbah rumah tangga yang merusak lingkungan. selain kedua bentuk respon tersebut, terdapat posisi masyarakat yang memiliki respon netral yaitu masyarakat yang tidak sama sekali melakukan kontak dengan pihak pemilik kerja bangunan dalam hal ini adalah tidak ada melakukan transaksi jual beli lahan dari pembangunan tersebut, hal lain adalah mereka merespon bahwa dari metodologi transaksi antara pihak pemilik proyek pembangunan dan masyarakat setempat yang menjual lahannya sama-sama diuntungkan dengan prosedur yang jelas.

\section{Dampak Sosial Terhadap Rencana Pembangunan Perumahan Regional Di Kawasan Pangi Desa Latali Kecamatan Pakue Tengah Kabupateng Kolaka Utara}

Kondisi masyarakat Kelurahan Latali mengalami perubahan sejak masuknya pembangunan perumahan yang menggunakan lahan pertanian untuk dijadikan kompleks perumahan, membuat masyarakat kehilangan mata pencahariaanya dari sumber pertanian yang selama ini merupakan mata pencaharian mereka dalam pemenuhan kebutuhan hidup keluarganya dan kebutuhan lainnya.

\section{a. Pola Kehidupan Masyarakat Kelurahan Latali Sebelum Masuknya Pembangunan Perumahan}

Pola hidup masyarakat yang dilakukan berupa kebiasaan untuk mencari nafkah dalam memenuhi kebutuhan hidup keluarganya dalam kehidupan sehari-hari, seperti pertanian, perkebunan dan perdagangan. Dapat pula kita ketahui bahwa mayoritas penduduk masyarakat yang tinggal diperkampungan diduduki oleh petani yang merupakan pencaharian utama mereka dalam memenuhi kebutuhan-kebutuhan sehari-hari serta sebagian untuk kepentingan sosial. Kondisi kehidupannya tidak terlalu kesusahan mengatur kebutuhan keluarganya. pendapatan utama masyarakat kebanyakan dari sektor pertanian dan jarang dari mereka usaha sampingan atau mencari penghidupan diluar dari sektor pertanian. Mereka hanya mengandalkan penghasilan dari sektor pertanian telah dilakukannya sejak lama yang telah dikerjakan secara turun-temurun sampai sekarang.

Kondisi Kelurahan Latali sebelum masuknya pembangunan perumahan adalah sebagai berikut:

1. Desa Latali sebelum adanya pengembangan pembangunan perumahan Lahan pertanian belum beralih fungsi menjadi perumahan.

2. Pendapatan utama dari sektor pertanian seperti cengke, kakao, dan pada tahun $\mathbf{2 0 1 0}$ minyak nilam.

3. Sarana dan prasarana masih buruk

4. Kesadaran pendidikan sangat rendah

5. Kebanyakan penghuninya masih penduduk asli setempat dan jauh dari keramaian

6. Perempuan atau Ibu rumah tangga belum terlibat langsung dalam mencari nafkah keluarga

7. Tingkat kriminal masih tinggi karena keadaan pemukiman perkampungan sangat seram (gelap)

8. Terfokusnya pendapatan mereka dari sektor pertanian tanpa adanya pekerjaan sampingan membuat masyarakat Desa Latali sebelum adanya pembangunan perumahan ekonomi atau pendapatan mereka kebanyakan menengah kebawah tetapi mereka tidak terlalu kesusahan mengatur kebutuhan mereka sebab dalam memenuhi kebutuhan pokoknya berasal dari hasil tani sendiri baru sisanya dijual untuk kebutuhan-kebutuhan lainnya. 


\section{b. Pola Kehidupan Masyarakat Desa Latali Setelah Masuknya Pembangunan Perumahan}

Pembangunan kompleks perumahan yang dilakukan developer menyebabkan berkurangnya lahan pertanian. Lahan pertanian merupakan sumber daya yang sangat dibutuhkan manusia untuk memenuhi kebutuhan hidupnya, dengan tingginya jumlah perubahan penggunaan lahan pertanian menjadi lahan nonpertanian, salah satunya adalah perumahan. Hal ini telah berdampak terhadap perubahan pola kehidupan masyarakat.

Kondisi masyarakat setelah masuknya pembangunan perumahan yaitu:

1. Lahan pertanian sudah berali fungsi menjadi perumahan.

2. Pendapatan utama diluar dari sektor pertanian dimana masyarakat menjadi buruh bangunan, penjual sayur, penjual ikan dan bisa jadi menjadi penyiram taman di perumahan.

3. Sarana dan prasarana sudah baik dimana jalanan sudah diaspal/dibeton dan lampu jalan sudah dipasang sehingga kondisi perkampungan sudah terang pada malam hari.

4. Kesadaran dalam pendidikan mulai ada ini terlihat masyarakat mulai melirik pendidikan sebagai inpestasi masa depan dimana dari mereka sudah ada beberapa lanjut keperguruan tinggi.

5. Banyaknya pendatang yang datang dari luar membuat Latali menjadi ramai.

6. Perempuan atau Ibu rumah tangga sudah mulai terlibat langsung dalam mencari nafkah keluarga dimana mereka mendirikan tempat penjualan dipinggir jalan untuk menjual buahbuahan dan sayur-sayuran.

7. Tingkat kriminal mulai berkurang dimana lingkungan sudah ramai dan adanya pemasangan lampu jalan sehingga masyarakat sudah berani beraktipitas pada malam hari.

8. Kondisi kehidupannya mengalami semakin sulit mengatur kebutuhan keluarganya karena pendapatan yang tidak menentu dan kebutuhan pokok serbah dibeli dan harganya semakin naik.

Banyaknya penggunaan lahan kesektor pembangunan perumahan kebanyakan dari mereka yang mempunyai lahan sebelumnya mencari penghidupan diluar dari sektor pertanian sedangkan masyarakat yang telah menjual lahannya tetapi dia masih mempunyai lahan untuk digarap tetap jadi petani meskipun bertani tidak dianggap lagi produktif. Efek dari pembangunan perumahan membuat lahan persawahan semakin rusak, ini tidak lepas dari perairan irigasi tidak lagi memadai sehingga persawahan sering mengalami kegagalan panen. Para petani ketika musim hujan lahan persawahan mengalami kebanjiran dan musim kemarau lahan persawahan mengalami kekeringan. Inilah yang menyebabkan para petani tidak lagi menjadikan sektor pertanian sebagai pendapatan utama.

Hal ini yang menyebabkan masyarakat mulai berali profesi karena sektor pertanian tidak dapat lagi dijadikan sektor pendapatan utama, kebanyakan dari mereka bekerja sebagai buru lepas. Dimana mereka setelah tidak lagi bertani kebanyakan dari mereka menjadi tukang bangunan di perumahan yang sementara dalam tahap penyelasaian pembangunan selain itu beberapa dari mereka menjadi pembudidaya ikan dan penjual sayur.

Pengembangan pembangunan perumahan yang terus terjadi dilakukan oleh pengembang (develover), dengan menggunakan lahan pertanian masyarakat sehingga lahan pertanian semakin berkurang. Menurut informasi yang didapatkan oleh peneliti dari hasil obsevasi maupun hasil wawancara baik dari pemerintah setempat maupun tokoh masyarakat yang ada di Desa Latali konversi lahan pertanian beralih ke pembangunan perumahan mencapai 40-45\%. Hal ini membuktikan bahwa penggunaan lahan pertanian menjadi nonpertanian sanagat meprihatinkan dan harus dicarikan jalan keluar ketika kita masi ingin melihat sektor pertanian tetap bertahan.

\section{c. Pola Hubungan Sosial Antara Masyarakat Perumahan Dan Masyarakat Sekitar}

Keberadaan kompleks perumahan disekitar pemukiman perkampungan masyarakat memiliki karakteristik tersendiri di Desa Latali. Karakteristik yang dimaksud gejala kompleks perumahan itu terlihat ekslusif terpisah dengan penduduk asli sekitarnya, keterpisahan itu cenderung menimbulkan 
gejala adanya batas budaya, sehingga potensi timbulnya masalah sosial. Relasi sosial warga masyarakat kompleks perumahan dan pemukiman cenderung tidak berjalan dengan baik. Pertentangan atau gangguan-ganguan dalam masyarakat biasanya sangat rawan terjadi, Fenomena ini bisa terjadi disebabkan oleh tidak terjalinnya hubungan sosial dengan baik karena tidak mencapai titik dari berbagai kepentingan.

Penekanan pada hubungan sosial antara warga masyarakat perumahan dan masyarakat sekitar, berdasarkan analisis ini ternyata begitu banyak komponen yang saling berhubungan satu sama lain yang membentuk suatu kerangka sistem sosial, baik positif maupun negatif. Dampak positif yaitu: Semakin luasnya pergaulan dan wawasan warga masyarakat pemukiman sehingga semakin menyadari akan pentingnya dunia pendidikan untuk berkembang, Kehidupan warga masyarakat kompleks perumahan menjadi motivasi bagi warga masyarakat perkampungan untuk berkembang baik dari aspek gaya hidup lebih bersih, keinginan untuk melanjutkan pendidikan untuk mendapatkan pekerjaan kesektor formal, terutama dikalangan generasi muda, terjalin kerja sama antara masyarakat perumahan dan masyarakat perkampungan di Kelurahan Samata diantarnya melalui kerja bakti dengan saling berpartisipasi dalam kegiatan bersama, saling membantu, dan saling pinjam meminjam barang.

Dampak negatif, Kompleks perumahan kelihatan ekslusif dan terpisah dengan penduduk sekitarnya, keterpisahan itu cenderung menimbulkan gejala adanya batas budaya sehingga potensi timbulnya kecemburuan dan konflik sosial, terdapat petunjuk dalam bentuk pertikaian atau perkelahian, hal ini terlihat pernah terjadi pemukulan pemuda yang tinggal diperumahan karena adanya kesala pahaman diantara mereka dan biasa terjadi pertentangan dan perselisihan antara masyarakat tinggal di perumahan dan masyarakat sekitarnya.

\section{KESIMPULAN}

Berdasarkan hasil uraian yang tekah dikemukakan berupah hasil pembahasan data dan informan data yang di peroleh di lokasi penelitian, maka dapat disimpulkan:

1. Perumahan merupakan salah satu kebutuhan pokok yang harus ada dalam melangsungkan hidup dan penghidupan manusia secara lengkap. Rumah adalah tempat untuk melepaskan lelah, tempat bergaul dan membina rasa kekeluargaan diantara anggota keluarga, tempat berlindung keluarga, dan menyimpan barang berharga, dan rumah juga sebagai status lambang social dan sebagai kebutuhan hidup.

2. Pandangan masyarakat terhadap aktivitas pembangunan yang dilakukan di kawasana pangi Desa Latali yang merupakan area yaitu baik. Dikarenakan, dapat menjdai salah satu alternatif masyarakat untuk menciptakan atau menjadi contoh salah satu hunian yang layak dan rapih, ketikah masyarakat hanya tinggal dan bermukim saja. Dengan adanya pembangunan perumahan ini di harapkan mampu mengubah kehidupan masrakat serta nilai guna tanah tentunya memiliki nilai ekonomi tinggi.

3. Dengan adanya kegiatan pembangunan perumahan di kawasan pangi Desa Latali adapun dampak positif dan negatif dari pendapat masyarakat setempat yaitu, dari segi positif. Dengan adanya pembangunan perumahan,lingkungan menjadi lebih tertatah dan lebih terliat rapih, mengenai lingkungan yang tadinya terbiarkan bisa bermanfaat. Dari segi negatif ya tentunya banyak dan masyarakat itu sendiri tau seperti dapat memicu terjadinya longsor, banjir di pemukiman, pengelolaan sampah dan pengaruh lingkungan lainnya.

\section{DAFTAR PUSTAKA}

Astrid S. Soesanto, pengntar Sosiologi dan Dampak Perubahan Sosial (Jakarta: Banacipta, 1985).

Asmutaqi.(2011), Pengembangan-Perumahan Berbasis-Pembangunan Infrastruktur.

Budihardjo Eko, (1998), Sejumlah Masalah Permukiman Kota, Alumni Bandung.

Bappeda Kabupaten lasusua (2001), Penyempurnaan Revisi Recana Tata Ruang Wilayah Kota

lasusua, kabupaten lasusua. 
Blaang, (1986), Perumahan dan Permukiman Sebagai Kebutuhan Pokok. Edisi Pertama, Yayasan Obor Indonesia, Jakarta.

Jurusan Pendidikan Sosiologi Universitas Muhammadiyah Makassar. 2013. Buku Pedoman Penulisan Karya Ilmiah Mahasiswa.

Sinulingga Budi D, (1999), Pembangunan Kota tinjauan Regional dan Lokal. Pusaka Sinar Harapan, Jakarta.

Simolingga. 1999. Pembangunan Kota. PustakaSinarHarapanAnggotalkapi: Jakarta Soerjono Soekanto, Pokok-Pokok Sosiologi Hukum (Jakarta: Raja grafind Prasada, 1994 ).

Sultan, (2002), Penyesuaian Lingkungan Pada Penduduk Pemukiman Liar di Perkotaan Kel.Karuwisi Utara Kec. Panakkukang Kota Makassar. PPS UNHAS.

Warpani, S. (1984).Analisis Kota dan Daerah. ITB, Bandung.

Yudohusodo S, (1991) Rumah Untuk Seluruh Rakyat. Yayasan Padamu Negeri, Jakarta.

Yunus, Hadi Sabari. 2000. Struktur Tata Ruang Kota. Pustaka Pelajar: Yogyakarta.

Zulkaidy, Denny. 1999. Pemahaman Perubahan Pemanfaatan Lahan Kota Sebagai Dasar Bagi Kebijakan Penanganannya, Jurnal Perencanaan Wilayah dan Kota: ITB: Bandung

Anwar, Yesmil dan Adang. 2008. Pengantar Sosiologi Hukum. Jakarta: Grasindo.

Ahmadi, Abu. 2003. Ilmu Sosial Dasar:Mata Kuliah Dasar Umum. Jakarta: Rineka Cipta.

Bungin, Burhan, M. 2008. Penelitian Kualitatif . Cet. II; Jakarta: Kencana Prenada Media Group.

Durkheim, Emile. (dalam Jonhson, Doyle, Paul; Terjemahan: Robert M.Z.Lawang). 1986. Teori-teori Sosiologi Klasik dan Modern, jilid 1 dan 2. Jakarta: Gramedia.

Fitriani, Erin. 2015. Dampak Pembangunan Perumahan Terhadap Kehidupan Sosial Ekonomi Masyarakat Setempat (Studi kasus Kehidupan Sosial Ekonomi Masyarakat di Desa Ligar Mekar Kelurahan Cibeunying Kabupaten Bandung). Tesis. UPI Bandung.

Hadi, Sudharta. 2002. Aspek Sosial Amdal; Sejarah, Teori dan Metode. Yogyakarta. Gadja Mada University Press.

http://dearch.blogspot.com/2016/11/pembangunan-perumahan-dan-pemukiman.html(Diakses 13 November 2016).

Moleong, Lexy J. 2007. Metode Penelitian Kualitatif. Bandung: Rosda Karya.

Surjadi, A 1983. Pembangunan Masyarakat Desa. Bandung: Penerbit Alumni.

Siagian, Sondang P. 2008. Administrasi Pembangunan: Konsep, Dimensi, dan Strateginya. Jakarta: Bumi Aksara.

Sugiyono. 2008. Memahami Penelitian Kualitatif. Bandung: Alpabeta.2009. Penelitian Kuantitatif Kualitatif. Bandung: Alpabeta. 